\title{
Transformative Learning in English Further Education
}

\section{Abstract}

This chapter draws on the Further Education in England: Transforming Lives \& Communities project, commissioned by UCU. This research project aims to understand and provide evidence of how the further education (FE) sector is vital in transforming lives and communities in 21st century Britain. The research provides learners, teachers, family members and their communities with the opportunity to tell their stories, linking the distinctness of FE to the impact it has on individuals, society and the economy.

The research provides evidence of how further education offers a "differential space" (Lefebvre 1991) that can subvert the prescriptive, linear spaces of compulsory education and lead to critical spaces for transformative learning. The study proceeds from an understanding that educational practices are positioned as ideologically imbued, driven and shaped by policy. Indeed, the model of curriculum can determine whether education is an emancipatory or oppressive process. While productivist approaches to vocational education and training support and perpetuate ideologies that legitimate and authenticate prescribed knowledge, reproducing inequality and injustice through the practices employed (Beck, 2005; Ade-Ojo and Duckworth 2016, Duckworth and Smith 2017b), transformative learning shifts to a more holistic and dynamic approach. It seeks engagement with learners through a purposeful acknowledgement of learners' cultural background and biography and nurtures critical insight into education as a socially-situated process. Transformative learning is orientated to affirming agency and as such, has a ripple effect that impacts on learners' families and their communities.

This chapter draws on a range of theoretical perspectives to provide an appropriate and illuminating framework to explore the themes around transformative learning that have emerged from the evidence. Amongst these, hope, space, egalitarianism and symbolic violence feature strongly. Learners' experience of symbolic violence (Bourdieu and Passeron 1991, Duckworth, 2013) was a key focus of our analysis. This symbolic violence consists of labelling individuals, reifying social division and the current (dis)order, and stymying creativity through the erasure of critical insights. It seeks to locate 'failure' within the individual as a determining and essentialist aspect of their identity thereby thwarting the development of empowering learner agency. Transformative learning spaces move beyond the symbolic and institutional violence that often shapes learners' understandings of themselves within the educational context and into a transformative critical space, restoring participants' hope and enabling them to transcend the internal and external influences and violence that have shaped their learning journey to date.

We suggest that in challenging inequalities in learners' lives and communities, adult education and vocational education and training should reflect a transformative pedagogy, providing a curriculum that is culturally relevant, learner-driven and socially empowering (Auerbach 1989; Duckworth \& Ade-Ojo 2016; Duckworth \& Smith 2017a; Freire, 1985; Giroux 1997; Lankshear \& McLaren, 1993; Quigley, 1997; Shor, 1992). 


\section{Introduction}

Nationally and internationally, globalisation and technological change have intensified economic competition, motivating governments to increase national growth, productivity, efficiency and innovation. The discourse that supports and underpins this competitive economic environment is driven by a neoliberal approach to learning societies which privileges individual over collective learning. As part of this, the focus of education according to neoliberal discourse (Ade-Ojo and Duckworth, 2016) is to provide a flexible, adaptable and skilled workforce to make countries competitive in the globalised economy. Thus, education is positioned as a commodity that, within existing social conditions, is more accessible to some groups than others. As such, education can be seen to support and entrench existing social, economic and social inequalities.

An overview of the political climate in England and recent key policies is helpful in contextualising our study. Since the 1980s research and debates surrounding class can be seen as being side-lined in political discourse. Indeed, traditional notions of class loyalty and solidarity, in many ways, were torn apart under Thatcherism. In 1997 New Labour came to power. Under this government, neoliberal approaches dominated and the notion of a classless society was seen and heard in their rhetoric of meritocracy and equal opportunities (Petras 2000). Central to the neoliberal vision, the opening up of health, education and other public services to competitive marketisation was underpinned by a rhetoric that foregrounded choice as empowerment (Ball 1993). Under this premise, individualism and self-improvement were promoted as were ideas - in an echo of the eugenicist views that epistemologically underpin the concept of IQ (Gould 1981) - that 'talent' is based on inherent ability rather than originating in privilege. As a principal organising feature of society, marketisation positions choice centrally: indeed, in neoliberal ideology, the agency of the individual is reduced and confined to exercising choice. However, there is overwhelming evidence that in economically unequal societies, choice is monopolised by those with enough resources/capitals and those who are at a structural disadvantage (e.g. those lacking economic capital) have fewer or no choices at all (Gewirtz et al. 1995; Whitty et al. 1998; Lauder et al. 1999, 1998; Archer et al. 2003; Reay 2004; Ball et al. 2000; Ball 2010, Duckworth, 2013, Duckworth \& Smith 2016). Viewed as a competitive ladder of opportunities / choices, the education system in England positions VET as a route for learners adjudged not to be 'academic' which in this case means learners who at 16 fail to achieve a national benchmark of attainment. As such, VET can be viewed as an educational trajectory that offers a low level of choice and agency.

Almost two decades ago, New Labour's The Learning Age document supporting Britain's drive for business and commerce, noted that: 'Learning will be the key to a strong economy and an inclusive society' (DfEE 1998: 3). Four years later, another key government policy document, Success for All, stated how the government's goals should be 'social inclusion and economic prosperity' (DfES 2002: 9) - this exemplified New Labour's Third Way and its discursive attempt to connect market capitalism with a social justice agenda. A more recent report, this time from a conservative-led coalition government: Fixing the foundations: boosting Britain's 
productivity (BIS 2015) illustrates the resilience of market rhetoric and its continued adherence to a view of education as, primarily, an aspect of human capital development.

Over the last century, productivity growth has gone hand in hand with rising human capital, as more people have become educated, and to a higher level. However, the UK suffers from several weaknesses in its skills base that have contributed to its longstanding productivity gap... Results from the OECD show that England and Northern Ireland are in the bottom four countries for literacy and numeracy skills among 16-24 year olds. (BIS 2015: 23)

This neoliberal imaginary, featuring a league table of national economies, provides the backdrop for recent educational policy in England. The recent relaunch of apprenticeships provides a good illustration of the impact of this. The government has redesigned and relaunched apprenticeships as the primary vehicle for bridging a perceived gap between education and work for a large section of the nation's young people. This latest version of apprenticeships signals a move away from previous approaches to VET that were designed for delivery by colleges and other further education providers. The new apprenticeships instead take a more work-based learning approach with employers very much 'in the driving seat' (BIS 2015, 23-26) as regards content, design and the focus on relevant skills.

Globalisation, competition and rapid progress of technology have also contributed to a shift in the nature and patterns of working life and employment. The current plans for the UK remain ambitious: in 2009, the UK Commission for Employment and Skills (UKCES) stated:

It is our ambition to be one of the top countries in the world - for jobs, for productivity and for skills. A World Class economy, built on World Class skills, supporting World Class jobs and businesses. We should aim to be in the top quartile of OECD countries in all three - jobs, productivity and skills - by 2020. This means being in the top eight countries of the world. Our future prosperity depends ultimately on employment and productivity: how many people are in work and how productive they are when they are in work. Skills are essential to both. If we are to become World Class, we must raise our game to match the productivity, skills and jobs of the best.

(UKCES 2009: 6)

The passage above provides strong evidence of the 'disenchantment of politics by economics' that Davies (2014) sees as a quintessential ideological achievement of neoliberalism. Ethical scruples are pushed aside and political considerations are neutralised by the common-sense assertion of the importance of government policy that focuses on the three hegemonic pillars of a 'World Class economy': jobs, productivity and skills. What is striking is that each of the terms in itself remains unexamined. For example, simply increasing the number of jobs available might hold little value if these jobs are low paid and do not connect with or rely on education and training (as is the case in England in 2017 see Thomson et al 2016); meanwhile, productivity as a decontextualised and dehumanised economic term that is often used in comparing the UK to other nations (See OECD 2017) but whose exact meaning remains so obscure it has assumed almost metaphysical properties; finally, skills appears to be a term which attempts to fix a generalised label onto a dynamic and shifting quality of human potential as defined (multifariously) by employers in a massively wide range of contexts.

The 'knowledge economy' concept that emerged during the New Labour period of British politics (1997-2010) has to some extent been replaced by a renewed focus on 'skills'. 'Skills' appears to be a term whose meaning is strongly influenced by conceptions of social class. When connected to educational discourse, it operationalises education as a conveyor belt for 
the production of a flexible, adaptable and skilled workforce to make countries competitive in the globalised economy. Neoliberal policy rhetoric promotes an instrumental model in which 'employability' in the labour market provides the key to social inclusion. 'Employability' - currently a trending education policy term - is part of a simplistic and reductive formula that conceptually connects education and training to a 'readiness to work' (Boden and Nedeva, 2010, p. 49-50). Employability has acquired a central role in policy, strategy and the student curriculum that blurs over the complexity of the relationship between vocational qualifications, learners' intentions, destinations and actual employment opportunities in the jobs market, and ignores the broader debate around the different purposes of education (see e.g. Biesta 2010). One aspect of the transforming lives project involved exploring the ways in which vocational education could offer transformative opportunities that moved beyond 'productivist' notions of the education / work relationship (see Dean's account below).

The notion of aspiration also appears as a sub-theme in the policy discourse on choice. Aspiration, like talent and motivation, is usually thought of as being immanent in individuals: a characteristic that can be shaped by choice. The individual can choose to have aspirations and can choose what aspirations to have. As such, an absence of aspiration or limited aspirations are blameworthy attributes. From a neoliberal perspective, that conceptualisation of aspiration ignores geographic constraints and the differing levels of capital accruing to different levels of the social strata that the marketised landscape offers to individuals; the same perspective sees aspirations as the responsibility of the individual, once more refusing to engage with the social factors and forces that may shape people's ability to aspire and what those aspirations are.

\section{The Further Education context in England}

Despite the dominance of the neoliberal skills discourse in policy, and the policy documents that position further education as a key part of a national skills-delivery mechanism, there has been a reduction in government funding for colleges in the last decade. For example, as part of the Coalition Government's 'austerity' measures, in the period 2009-14, courses for adults lost around 35\% of funding (UCU 2015). A redirection of finance towards Apprenticeships is taking place within a longstanding 'bums on seats' funding environment (Smith 2007, 43) that has been heavily criticised for leading to 'spoon-feeding', 'gaming' and a narrowed curriculum (O'Leary and Smith 2012, Smith and O'Leary 2013, Wolf 2011).

Our research provides evidence that despite the instrumentalisation of the curriculum in further education colleges, transformative learning is still taking place. Recognizing the power of education, and the enactment of the curriculum, to reproduce rather than challenge social inequality, offers a frame for understanding learners' narrative accounts of their educational and personal journey. The Further Education: transforming lives and communities ${ }^{1}$ research project sought to unfold learners' narratives, the overarching aim being to recognise and understand their narratives against the backdrop of wider socio/economic/political and historical contexts (Goodson \& Sykes, 2001; Goodson, 1992, Duckworth 2013, Duckworth and

\footnotetext{
${ }^{1}$ http://transforminglives.web.ucu.org.uk/
} 
Smith 2016, 17). The research cuts across the grain of the skills policy discourse, providing a picture of stubborn seedlings taking root in very stony ground.

\section{Theoretical connections: Freire, Bloch, Lefebvre and Bourdieu}

This research was informed by a standpoint that connects critical theory to education theory and, specifically, critical pedagogy (Brookfield, 2000; Darder, Baltodano, \& Torres 2009; Duckworth 2013). Critical pedagogy draws primarily on the work and writing of Paulo Freire whose seminal book Pedagogy of the Oppressed expressed the need for a radical change to the traditional 'front-end loading' approach to teaching and learning that he characterised as a 'banking system of education' (Freire, 1996). Freire's work, founded on his educational experiences with indigenous people in Brazil, is important as it takes social inequality as a given and articulates an emancipatory and conscious-raising role for education in the light of a socially inequitable context.

The research project drew on Freire's work and on the tradition of critical reflective practice (Brookfield 1995) which utilises the interrelationship between past, present and future. The rekindling of hope, the re-alignment of perspective (called 'perspective transformation' by Mezirow, 1990) and a subsequent resurgence of agency are all features of transformative learning. The project sought to gather learners' narratives to illustrate how further education in England provides experiences of transformative learning. Freire (1996) argued that critical educational practice is not a specific methodology to be applied without insight but rather one that emerges when tutors can practise teaching from a critical perspective and have the time to reflect on their pedagogy. Critical pedagogy shifts away from teacher-directed, top-down, commonly imposed and standardised assessments that prescribe the same for all students, regardless of their ability, values, ethnicity, history, their community requirements or their specific contexts. Instead it takes an egalitarian approach, whereby there is a sharing of power between the teacher and the learner in learning, the curriculum, its contents and methods.

Critical pedagogy resonated within the research as it provided an explanatory picture for teachers' approaches as they strove to provide educational environments in which transformative learning could take place. This meant challenging the 'abstract space' that further education has become. Policy discourse that uses the notion of a 'sector' reifies a generalised perception that colleges are somehow interchangeable and that the diverse contexts in which colleges are situated can be ignored. In this way, further education space is 'produced' as 'dominated space' (Lefebvre 1991) to be manipulated in the service of the neoliberal aims of producing human capital for industry.

Critical pedagogy necessarily involves engaging fully with local context - while maintaining a wider perspective. It utilises Freirean 'culture circles' (1996) - discussion groups in which educators and learners come together in dialectic engagement for consciousness raising, liberation, empowerment and transformation. Education for liberation provides a forum open to the empowerment of learners, teachers and the community, while also providing opportunities for the development of those skills and competencies without which empowerment would be impossible. Such emancipatory practices encourage autonomy and critical thinking, opening up spaces where learners and communities can ask questions, analyse and subsequently work through meaningful strategies to enhance their situation.

The research identified how transformative learning is a product of critical pedagogy. A key aspect of transformative learning is its focus on learners developing a critique of hegemony 
and inequality. Freirean 'conscientisation' allows people to understand that their educational disadvantage is not of their own making, but often of social and cultural forces beyond their control. In our study, hope is an integral aspect of the transformative learning environment. Rather than simply being an articulation of a daydream, this hope is connected to the realignment of perspective that learners experience regarding their position within wider society and how their prior educational experiences may have been inflected by these structural forces. In this sense, we see the work of Ernst Bloch as useful in illuminating how hope is fundamental in settings in which transformative learning takes place:

Desire, hope, anticipation, orientation towards the future: the central Blochian concepts all involve a potentially precarious relationship to the now. (Dhuill 2013: 157)

Bloch positions hope centrally as a key motive force in history through which the subject acts on reality. For him hope is "indestructibly grounded in the human drive for happiness and... has always been too clearly the motor of history" (Bloch 1986: 443). In terms of transformative vocational learning, the 'now' is located in the classroom and is part of the 'differential space' (Lefebvre 1991) offered in further education settings in which teachers help learners reorientate themselves as active agents able to shape their own narratives rather than having (e.g. skills) narratives imposed on them. First in this comes an acknowledgement that learners' educational histories may have damaged their hope; followed by an acknowledgement that a spark of hope remained - enough at least to encourage them to walk through the front door of a local college (or other institution) and back into a classroom. From there, supported within an affirmative learning environment, learners began a sometimes daunting but ultimately rewarding journey in which they (re)constructed a positive learning identity and reconnected this and educational experience to a personal future. This future sometimes took the form of a vocational course, and sometimes the form of a job or specific career trajectory.

In this way, hope can be seen to connect past to present and then link both to a specific future through the enactment of renewed agency. Viewed through this lens, critical pedagogy becomes an articulation of Bloch's theories as pedagogy that is fine-tuned as mediating action between learners and the future. Bloch's work focuses on 'the darkness of the lived moment' as containing within it the potential for positive transformation. Bloch's theories reach beyond the entrepreneurial tropes of the neoliberal imaginary by extending connecting the individual to the collective, not just in a primarily competitive relationship but in a relationship of solidarity and egalitarianism. Bloch's resurrection of hope becomes necessary in a neo-liberal landscape in which alternatives are rubbished and ridiculed and while, despite the 2008/9 financial crisis, the Thatcherite dictum that There Is No Alternative continues to resound.

Lefebvre's triadic conceptualisation of space as 'conceived space', 'perceived space' and 'lived space' (Lefebvre 1991) provided an important final theoretical strand for us to utilise to make sense of our data. Conceived space here links to the abstract space of further education as reified by policymakers. Lefebvre sees abstract space as:

an apparent subject, an impersonal pseudo-subject... and - hidden within it, concealed by its illusory transparency - the real subject, namely state (political) power... (Here), lived experience is crushed, vanquished by what is 'conceived of'. (Lefebvre 1991, 49-51).

VET and further education can both be viewed as 'abstract spaces' generalized, objectified and instrumentalised by policy makers. Against this abstract space, in a striking echo of 
Bloch's potential contained in 'the darkness of the lived moment', Lefebvre counterposes 'differential space':

abstract space carries within itself the seeds of a new kind of space. I shall call that new space 'differential space', because, inasmuch as abstract space tends towards homogeneity, towards the elimination of existing differences or peculiarities, a new space cannot be born (produced) unless it accentuates differences. $(1991,52)$

In this way, Lefebvre theorises the potential re-appropriation by ordinary people of abstract space. This theorisation enables us to understand how the version of further education envisaged in the neo-liberal imaginary of policy makers contains within it transformative learning environments.

The research focused on the learners and their educational journeys as experiential illustrations of the impact of social inequality and education's role in either reifying or challenging this. Bourdieu's concept of cultural capital was useful in exposing the transmission of wealth and power and incorporating ideas about how those in a position of power, who Puwar (2004) describes as 'insiders', reproduce and maintain their domination. Bourdieu's fields of social, cultural and economic power overlap and feed into each other, singly and together offering a valuable framework for understanding the historical formation and reproduction of the research group in this study. His concept of symbolic violence emerged as a powerful tool for explaining how transformative learning works often in contrast to earlier educational experiences.

\section{Transformative learning environments: evidence from research}

Data from the project provided a range of evidence about the different constituents of transformative learning environments. One key element relates to the way in which the curriculum relates to the learners' biographies. For most learners, this was as simple as being accepted for who they were:

My self-esteem and confidence wasn't what it was when I was eighteen. (Now) I'm comfortable in my own skin. And that's something to do with equality. And people at Northern College accepting you for you... And just that right to speak without being interrupted. I found that, like, so powerful. And being really listened to as well.

This theme of acceptance and affirmation was echoed by others, sometimes it was expressed in terms of the relationship that was formed with the college staff. Anita, a learner who went from dead-end jobs to a social work qualification expressed this in these terms:

My tutors are the ones that have got me here. They've got me this far. I don't know where I would have been without Judith and Margaret... They didn't push me, they encouraged me. They never once doubted me. They encouraged and they made me grow. Through that, I've been able to inspire my kids.

Here we also see another aspect of transformative learning: that is the intergenerational ripple effect. Anita's renewed hope and agency has had the knock-on effect of providing an environment in which her children feel motivated and able to connect their educational achievements to their becoming-biographies. It is revealing to contrast this with the assumptions about learner agency within the neoliberal skills discourse. To return to the image used in the Building the Foundations policy document (BIS 2015):

Professional and technical education provision... needs to be refocussed to deliver the higher level skills that employers need. Strong institutions are needed to support this 
ambition.... The government will... invite some colleges to become prestigious Institutes of Technology to deliver high-standard provision at levels 3, 4 and 5.... Institutes of Technology will be sponsored by employers, registered with professional bodies and aligned with apprenticeship standards. The government will empower National Colleges, Catapults, and elite professional institutions to design each route, alongside employers and professional bodies. (BIS 2015, 25-26)

This passage comes from a section of the document entitled Putting employers in the driving seat. The overview here is of policy that aims to change not just course content but also the structures and cultures of colleges better to meet employers' needs. Notable by its absence is any mention of learners' needs, hopes or requirements. The inference here is that employers' needs are the priority and that the curriculum as it stands is failing to meet to them.

In curricular terms, this position is in direct opposition to the kind of differential space that characterises the transformative learning environment. Transformative learning necessitates a curriculum in which the learner takes a central position, certainly at the start of a course and then, as autonomy and confidence grows, less pervasively. The research evidence on this is encapsulated well by one of the teacher participants. In our research conversation, Jez talked about his passion for teaching Level 1 and Level 2 Business students. The learning environment Jez sought to establish in the classroom reversed the low expectations that many of his students brought with them from their prior educational experiences. A principal technique Jez used was to foster autonomy. Interestingly, he uses the same metaphor as the Building the Foundations document.

I don't see it as me and them... We are all one... we work together, so when they are driving their own bus, initially, I'm driving it. I'm showing them where the gear stick is, I'm showing them where the steering wheel is. But as their confidence builds, as they get more familiar with... the expectations... I place on them, they take over the reins, and they start driving the bus. So they dictate which way they want the course to go on, what units they want to do within the course... that's a huge step for some of the under-privileged learners that I come across - to be given that power.

The egalitarian approach here is not about the teacher ceding authority in the classroom. But rather, in her/him using that authority to establish a particular environment in which a traditional uni-directional, transmission-orientated power dynamic is replaced by one which is more differentiated and collective and which requires learners to take on a role of responsibility in making decisions about the curriculum. Whether or not this might meet the 'needs of employers', appears to be beside the point as this curriculum interweaves curriculum content with personal development. Jez was however, convinced that without his approach, many of the learners would not have succeeded on the course to start with.

Another participant, Dean, offered an insight into how a transformative learning environment could meet an employer's needs while also acting as a catalyst for personal and professional development. In Dean's case, his employer liaised closely with the college to ensure a construction curriculum that was appropriate. But the employer relied absolutely on the expertise and the affirmative approaches adopted by the college teaching staff. For Dean then, attending college meant overcoming the significant barrier of a lack of self-confidence.

Given the opportunity to further myself, that's a no brainer. But then coming to college, that first day, I was like: I'm not sure I can do this.... It's changed me. I can do things. 
I am capable. It's changed me and like things are possible. The first day I started I had no computer skills... Now I feel like I've got a bit of respect. It's definitely life-changing... Even with the kids, I went to parents' evening... I ended up chatting (to the teacher) more about me than about (my daughter).... I've been promoted to be site manager. It's been an amazing turnaround.

Simon, the managing director of a construction company and Dean's employer talked about the importance of 'growing' his own talent, and revealed a holistic approach to this kind of education that demonstrated a full commitment to his employees, many of whom he has seen flourish as a result of returning to study. Simon saw construction as a vocation and a career with opportunities for personal growth and the development of skills and knowledge.

I've built a five year course - when people say an apprenticeship, (normally) it's two years. I've been absolutely saddened by the attitude of the industry where it is encouraged and rewarded to collect as many apprentices as you can, massive intake then after two years, you take an eighteen year old and you say: I'm sorry there's no future with us.... The driving force for us is, you pass and do your apprenticeship with us and you are guaranteed a career. That's part of the deal... you work hard for me, you work hard for the business and we will look after you and we will guarantee you a framework.

Within Simon's contribution there is an explicit criticism of employers' existing attitudes to state-funded VET - an attitude that seems to exploit it as a form of state-subsidised labour that can be jettisoned once the funding is used up. It's possible that that is a default position for employers towards VET initiatives under existing marketised arrangements. Simon's approach is very different and, through the transformative experiences on offer at the college, seeks to connect the success of his company with the personal development of the employees. In his case, there is space alongside the learner and the teacher on the 'driving seat' and his is an enabling rather than a dominant role.

\section{Education and symbolic violence}

Transformative pedagogies are a response and an antidote to the symbolic violence experienced by many learners in their compulsory education. The power of symbolic capital and what is valued and why in different fields offered an insightful avenue of enquiry into the experiences of the learners in this study. It allowed for a further understanding of the symbolic violence the learners were subjected to and its impact on their lives. Indeed, drawing on the learners' narratives, we could identify features of symbolic violence that were embedded in their everyday life. This allowed us to explore the different forms of violence that can co-exist and indeed support one another, each interacting with and amplifying each other.

The relationship of symbolic violence to learning and the impact it had on participants' sense of themselves as effective and successful learners emerged strongly from the data. The symbolic violence that the learners had experienced was often hidden because it triggered feelings of shame in the individual. Adam provided a powerful example. Adam was a sixteen year old who was excluded from his local school and explained how one reason for this was that he had anger management problems:

In school I was getting angry quite a lot. I was punching walls... I used to think I was dumb all the time in school. I had no hopes at all.... 
The knock on effects for Adam's family and home life were significant. His mother described how she received phone calls every day and sometimes had to leave work in order to pick her son up from school. Adam's sense of being 'dumb' and ignored was, in his mind connected to teachers' labelling as coming from a particular estate with a 'reputation': this created negative expectations that meant his identity as a learner was severely compromised:

I was in a lesson and I was there with my hand up asking for help and there was another person with their hand up asking for help. I'm the naughty one and he was a good lad and I was quite naughty. So (the teacher) went straight to him and then another person put their hand up and then another person even though I had my hand up. And he kept going round and round until after nine people then he come to me. And that was why I was getting angry... Everyone just looks at you and they think Oh yeah... They judge a book by its cover and you shouldn't do that.

In Adam's story symbolic violence is observed as an outcome of the way the teacher relates to and interacts with the learner. As with Anita - who talked about being put 'in a box' symbolic violence takes the form of an ongoing assessment of 'ability' that shapes social interactions between teacher and learner. At this point, we need to revisit Bourdieu's original conceptualisation of symbolic violence.

Bourdieu and Passeron (2013: 3-68) write about the symbolic system that education draws on to inculcate and impose meanings on learners. They see education as imposing a standard culture whose values reflect the social structure and the power relations that underpin it. In other words, education perpetuates inequality and a stratification of individuals in a way that serves to replicate existing social inequalities.

Bourdieu and Passeron argue that there is a 'twofold arbitrariness' in pedagogic action (ibid. 5-6). The first arbitrary is the power underpinning pedagogic authority; the second is the 'cultural arbitrary' that the pedagogy seeks to impose. Pedagogic action can only take place with pedagogic authority which he sees as:

a power to exert symbolic violence which manifests itself in the form of a right to impose legitimately (which) reinforces the arbitrary power which establishes it and which it conceals. (Bourdieu and Passeron 2013: 13)

Pedagogic action for Bourdieu and Passeron constitutes symbolic violence because it entails the imposition of arbitrary meanings and cultural values on learners. But while Bourdieu and Passeron dismiss the possibility of a critical pedagogy which foregoes symbolic violence, seeing no pedagogic action as 'culturally free' (ibid. 17), their model is very transmissive. It adopts a view of educational experiences as experiences in which learners are recipients rather than co-constructors of meaning. Bourdieu and Passeron see education as affirming the cultural background of some children while delegitimising that of others. In this sense pedagogic action imposes a recognition of the legitimacy of the dominant culture on members of dominated groups, classes and individuals, but it also imposes on them by the inculcation of exclusion, a recognition of the illegitimacy of their own culture.

So how is it possible to theorise transformative learning in the light of Bourdieu and Passeron's thinking on symbolic violence and the 'twofold arbitrariness of pedagogic action'? We would argue that the twofold arbitrariness of pedagogic action at the heart of the notion 
of symbolic violence is specifically addressed in transformative learning environments. The first arbitrary: the power underpinning the pedagogic authority is addressed through the egalitarian relations that the teacher strives to establish. The second aspect, the 'cultural arbitrary' that pedagogic action seeks to impose is addressed through the inclusion and (even) centrality of learners' biographical experiences in the curriculum. Evidence from learners and teachers in the research repeatedly returns to these characteristics; and learners' narratives in particular repeatedly contrast transformative learning environments with prior educational experiences in which they felt judged and labelled in a disabling way.

\section{Conclusions: transformative learning and critical research practice}

The research findings underscore how the neo-liberal assumption that individuals are free to determine their own pathways is severely tested by evidence about the impact of structural and historical inequalities: gender, race, class and other markers of identity that clearly shaped the learners' educational journeys. Our research shows educational institutions are not neutral in the value placed on the accumulation of capital and its transmission; and teachers also play a role in this. One way in which this happens is that learners from disadvantaged backgrounds are not considered to have the right attributes to progress (Archer et al. 2003; Burke 2006). Indeed, many of the participants in this study were faced with exclusion underlining how choice for the 'excluded poor/dispossessed working class is, mostly, a myth' (Byrne 2005: 141).

However, this evidence of symbolic violence was in each case counterbalanced by the research participants' narratives of transformative learning in further education settings. It would be a gross generalisation to claim that all or even most further education teachers typically 'set right' the mistakes created by school teachers. But the instrumentalism of policy discourse about VET has not extinguished the potential for further education to offer transformative learning experiences. There is research evidence that suggests that teachers isolated within managerialist institutions 'spoon-feed' learners to achieve targets and ensure the flow of funding (e.g. Literacy Study Group 2008). However, our project evidence so far indicates that transformative learning experiences do exist. The 'second chance' educational opportunities offered by further education by definition follow on from prior educational experiences and the evidence from this project is that further education can offer a 'differential' rather than a 'dominated' space. Despite the instrumentalism of the neoliberal skills discourse and the inhibiting effect that this has on teaching and learning in colleges, transformative learning still happens - though there is little detailed evidence about its extent.

A vital ingredient of the transformative learning environment is its orientation towards nurturing hope in learners. Hope and the idea that education might relate positively to one's agency, future life experience and socio-economic position is undermined by symbolic violence as theorised by Bourdieu and Passeron. In Bloch's terms, transformative learning environments act on and catalyse learners' hope. They identify the points of entry and potential movement in learners' lives in the world, the 'openness of the object-based background' within 'the darkness of the Now' and help learners identify a way forward, the potential of an 'outflow' (Bloch 1986: 289).

Our research uncovered the stories of learners who were able to change the way they interpreted their experience (Duckworth and Smith 2017) as a stage in the revitalisation of their agency as learners; this then led to transformation. The learners' narratives revealed how making sense of their structural positioning as adult learners in a society based on inequality 
of opportunity and choice enabled them to challenge the prescriptions of symbolic violence and move their lives forward.

With the seeming demise of neoliberal policies and the gloomy prospects they offer: of ongoing austerity; of the never-ending spiral of increased productivity in a world of finite natural resources; of performativity as a mediation of this; of the obliteration of truth in the name of market expedience; of the subjugation of human beings to economic ends; - in this context, what is needed is a shift in the understanding of policy makers away from the determinist and instrumental vision of education that objectifies learners in the service of the neoliberal project of despair. Instead, an acknowledgement of the importance of further education as a 'differential space' for critical reflection, renewal and hope is necessary. This would enable further education practitioners to move away from competence-based models and the spoon-feeding approach necessitated by current funding arrangements to holistic approaches (see Morrish et al. 2002) informed by dialogic care (Duckworth 13, 2014) that can provide more of the transformative learning opportunities found in our research and for the resurrection of hope.

\section{References}

Ade-Ojo, G. and Duckworth, V. (2015) Adult Literacy Policy and Practice: From Intrinsic Values to Instrumentalism. Palgrave Macmillan Pivotal: London Ade-Ojo, Gordon and Duckworth, V. (2016) Of cultural dissonance: the UK's adult literacy policies and the creation of democratic learning spaces. International Journal of Lifelong Education. pp. 1-18. ISSN 0260-1370 DOI 10.1080/02601370.2016.1250232

Archer, L. and Leathwood, C. 2003. 'Identities, inequalities and higher education', in L. Archer, M. Hutchings and A. Ross (eds) Higher Education: Issues of Inclusion and Exclusion. London: Routledge Falmer.

Ball, S. J. 1993. Education Markets, Choice and Social Class: the market as a class strategy in the UK and the USA, British Journal of Sociology of Education, 14:1, 3-19.

Ball, S., Maguire, M. and Macrae, S. 2000. Choice, Pathways and Transitions Post16: New Youth, New Economies in the Global City. London: Falmer Press.

Ball, S. J. (2010) 'New class inequalities in education: why education policy may be looking in the wrong place! Education policy, civil society and social class', International Journal of Sociology and Social Policy, 30 (3/4): 155-166.

Biesta, G. J. J. 2010. Good education in an age of measurement: Ethics, politics, democracy. Boulder, Co: Paradigm Publishers.

Bloch, E. 1986. The Principle of Hope. Volume 1. Oxford: Blackwell.

Boden, R. \& Nedeva, M. 2010. 'Employing discourse: Universities and graduate' employability". Journal of Education Policy, 25: 37 - 54.

Brookfield, S. 1995. Becoming a Critically Reflective Teacher. San Francisco: Jossey-Bass.

Brookfield, S. 2000. Transformative Learning as Ideology Critique. In J. Mezirow (Ed) 
Learning as transformation: Critical perspectives on a theory in progress San Francisco:Jossey-Bass

Bourdieu, P. and Passeron, J-C. 2013. Reproduction in Education, Society and Culture. London: Sage.

Burke, P. J. 2006. "Fair access?": Exploring gender, access and participation beyond entry to higher education', in C. Leathwood and B. Francis (eds) Gender and Lifelong

Learning: Critical Feminist Engagements, pp. 40-53. London: Routledge. Byrne, D. 2005. Social Exclusion. Buckingham: Open University Press.

Darder, A., Baltodano. M.,Torres. R. D (Eds.) 2009. The critical pedagogy reader. New York, NY: Routledge.

Department for Business, Innovation and Skills (BIS) / HM Treasury. 2015. Fixing the Foundations: creating a more prosperous nation.

https://www.gov.uk/government/publications/fixing-the-foundations-creating-a-moreprosperous-nation. Accessed 15.08.17.

Department for Education and Employment (DfEE) 1998. The Learning Age: A Renaissancefor a New Britain (Green Paper CM 3790). London: The Stationery Office.

Department for Education and Skills (DfES) 2002. Success for All. London: DfES.

Duckworth, V. 2013. Learning Trajectories, Violence and Empowerment amongst Adult Basic Skills Learners. Research in Education. London: Routledge

Duckworth, V. 2014. Literacy and Transformation, in Duckworth, V. and Ade-Ojo, G. (eds.) Landscapes of Specific Literacies in Contemporary Society: Exploring a social model of literacy. Monograph: Routledge Research in Education: London pp 27 - 46

Duckworth, V. \& Smith, R. 2017a. Further education in England - Transforming lives and communities: Interim Report. UCU

http://transforminglives.web.ucu.org.uk/2017/01/19/further-education-in-englandtransforming-lives-and-communities/

Duckworth, V and Smith R. 2017b. UCU research transforming lives and communities. A national practitioner guidance booklet is being developed with a focus on transformative education.

http://transforminglives.web.ucu.org.uk/2017/06/05/sharing-transformational-approachesto-teaching-and-learning/

Feeley, M. 2007. Adult Literacy and Affective Equality: Recognising the Pivotal Role

of Care in the Learning Relationship. Dublin University: unpublished PhD.

Freire, P. 1985. The politics of education: Culture, power, and liberation. South Medley, MA: Bergin and Garvey.

Freire, P. 1996. Pedagogy of the Oppressed. London: Penguin.

Freire P. 2004. Pedagogy of Indignation. London: Paradigm Publishers.

Gewirtz, S., Ball, S. J. and Bowe, R. 1995. Markets, Choice and Equity in Education. Buckingham: Open University Press.

Giroux, H. 1997. Pedagogy and the Politics of Hope: Theory, Culture, and Schooling. Boulder,CO: Westview.

Goodson, I. F. and Sikes, P. 2001. Life History Research in Educational Settings: Learning from Lives. Buckingham: Open University Press.

Goodson, I. 1992. 'Studying teachers' lives: an emergent field of inquiry', in I. Goodson (ed.) Studying Teachers' Lives, pp. 1-17. London: Routledge.

Gould, S. J. 1996. The Mismeasure of Man. New York: Norton.

Lankshear, C. and McLaren, P. (eds) 1993. Critical Literacy: Politics, Praxis, and the 
Postmodern. Albany, NY: State University of New York Press.

Lauder, H., Hughes, D., Watson, S. et al. (1999) Trading in Futures: Why Markets in Education Don't Work. Buckingham: Open University Press.

Lefebvre, H. 1991. The production of space. Oxford: Blackwell.

Literacy Study Group. 2008. "Sometimes no amount of reflection or theory helps' -

thoughts on the 'quality' of Literacy provision across a range of Black Country providers'. Journal of Vocational Education \& Training. 60:4, 441-454.

Mezirow, J. 1990. Fostering Critical Reflection in Adulthood, San Francisco: JosseyBass.

Morrish, E., Horsman, J. and Hofer, J. 2002. Take on the Challenge: A Sourcebook from the Women, Violence, and Adult Education Project. Washington, DC: United States Department of Education, Women's Educational Equity (WEEA) Program.

Ni Dhuill, C. 2013. Engendering the future: Bloch's utopian philosophy in dialogue with gender theory. In Thompson, P and Zizek, S. 2013. The privatisation of hope. Durham N. C.: Duke University Press 144-163.

O'Leary, M. \& Smith, R. 2012. Earthquakes, cancer and cultures of fear: qualifying as a Skills for Life teacher in an uncertain economic climate, Oxford Review of Education. 38:4, 437-454.

OECD. 2017. Compendium of Productivity Indicators. http://www.oecd.org/std/productivitystats/oecd-compendium-of-productivity-indicators-22252126.htm. 30.08.17.

Petras, J. 2000. The Third Way: Myth and Reality. The Monthly Review. 51: 10. https://monthlyreview.org/2000/03/01/the-third-way/. 30.08.17.

Puwar, N. 2004. Space Invaders: Race, Gender and Bodies out of Place. Oxford: Berg.

Reay, D. 2004. "“It's all a habitus"; beyond the habitual use of habitus in educational research', British Journal of Sociology of Education, 25 (4): 431- 444.

Shor, I. 1992. Empowering Education: Critical Teaching for Social Change. Chicago, IL: University of Chicago Press.

Smith, R. \& O'Leary, M. 2013. New Public Management in an age of austerity: knowledge and experience in further education, Journal of Educational Administration and History, 45:3, 244-266.

Smith, R. 2007. Work, Identity and the Quasi-market: The FE Experience, Journal of Educational Administration and History, Special Practitioners' Research Edition, 39: 1, 3347.

Thompson, S., Colebrook, C., Hatfield, I. and Doyle, P. 2016. Boosting Britain's lowwage sectors a strategy for productivity, innovation and growth. Institute for Public Policy Research.

https://www.ippr.org/files/publications/pdf/low-wage-sectors May2016.pdf. 30.08.17.

UK Commission for Employment and Skills (UKCES) 2009. Ambition 2020: world class skills and jobs for the UK. http://webarchive.nationalarchives.gov.uk/+/http:/www.ukces.org.uk/PDF/UKCES FullRep ort USB A2020.pdf. 30.08.17.

University and College Union (UCU). 2015. UCU briefing on $24 \%$ cuts to adult further education budget in England.

https://www.ucu.org.uk/media/7108/FE-England-budget-cuts-2015-16---a-UCUbriefing/pdf/ucu fecutsbriefing feb15.pdf. 25.08.17.

Whitty, G., Power, S. and Halpin, D. 1998. Devolution and Choice in Education. 
Buckingham: Open University Press.

Wolf, A., 2011. Review of vocational education - the Wolf report.

https://www.gov.uk/government/uploads/system/uploads/attachment data/file/180504/DFE -00031-2011.pdf. 17 August 2017. 